\title{
Chagas disease ecoepidemiology and environmental changes in northern Minas Gerais state, Brazil
}

\author{
Elisa Neves Vianna ${ }^{1 /+}$, Ricardo José de Paula Souza e Guimarães ${ }^{2}$, \\ Christian Rezende Souza ${ }^{3}$, David Gorla ${ }^{4}$, Liléia Diotaiuti ${ }^{5}$
}

\begin{abstract}
'Universidade de Brasília, Faculdade de Medicina, Departamento de Patologia, Brasília, DF, Brasil
${ }^{2}$ Instituto Evandro Chagas, Direção Geral, Laboratório de Geoprocessamento, Ananindeua, PA, Brasil

${ }^{3}$ Alô Meio Ambiente e Geoprocessamento Ltda., Belo Horizonte, MG, Brasil

${ }^{4}$ Universidad Nacional de Córdoba, Instituto de Altos Estudios Espaciales Mario Gulich, CONICET, Córdoba, Argentina

${ }^{5}$ Fundação Oswaldo Cruz-Fiocruz, Centro de Pesquisas René Rachou, Laboratório de Triatomíneos e Epidemiologia da Doença de Chagas, Belo Horizonte, MG, Brasil
\end{abstract}

BACKGROUND Triatoma sordida and Triatoma pseudomaculata are frequently captured triatomine species in the Brazilian savannah and caatinga biomes, respectively, and in Brazilian domiciles.

OBJECTIVES This study identified eco-epidemiological changes in Chagas disease in northern Minas Gerais state, Brazil, and considered the influence of environmental shifts and both natural and anthropogenic effects.

METHODS Domicile infestation and Trypanosoma cruzi infection rates were obtained from triatomines and sylvatic reservoirs during the following two time periods: the 1980s and 2007/2008. Entomological and climatic data with land cover classification derived from satellite imagery were integrated into a geographic information system (GIS), which was applied for atmospheric correction, segmentation, image classification, and mapping and to analyse data obtained in the field. Climatic data were analysed and compared to land cover classifications.

RESULTS A comparison of current data with data obtained in the 1980's showed that $T$. sordida colonised domiciliary areas in both periods, and that T. pseudomaculata did not colonise these areas. There was a tendency toward a reduction in $T$. cruzi infection rates in sylvatic reservoirs, and of triatomines captured in both households and in the sylvatic environment. T. sordida populations have reduced in the sylvatic environment, while T. pseudomaculata showed an expanding trend in the region compared to counts observed in the 1980's in the sylvatic environment. This may be related to high deforestation rates as well as gradual increases in land surface temperature (LST) and temperatures along the years.

MAIN CONCLUSIONS Our results suggest a geographical expansion of species into new biomes as a result of anthropogenic and climatic changes that directly interfere with the reproductive and infection processes of vectors.

Key words: Chagas disease - Triatoma - epidemiology - geoprocessing

Chagas disease (CD), also known as American trypanosomiasis, is a parasitic disease caused by Trypanosoma cruzi, which is transmitted by the Triatominae (Reduviidae). Triatoma sordida is the most frequently captured triatomine in Brazil, including northern Minas Gerais state. This species is also found in the Chaco region of Argentina, Paraguay, and Bolivia (Carcavallo et al. 1999). The vector is endemic in the Cerrado biome, where it invades homes and colonises peridomiciles (Oliveira \& Silva 2007). The species has broad distribution in nature, and adult dispersion occurs mainly by the end of the first half of the year (Forattini et al. 1983). In an artificial environment, T. sordida is ornithophilic and is often found in chicken coops (Diotaiuti et al. 1995a). However, it is an opportunistic species and can feed on humans (GonzálezBrítez et al. 2014). In the sylvatic, it utilises different food sources (Diotaiuti et al. 1993).

doi: 10.1590/0074-02760170061

Financial support: CNPQ (300.679/2011-4), WHO/TDR-World Health Organization (no A70506).

+ Corresponding author: ramarrina@gmail.com

Received 9 February 2017

Accepted 1 June 2017
Triatoma pseudomaculata is another Brazilian autochthonous vector of Chagas disease. It is associated with the Brazilian semiarid region and colonises peridomiciles frequently and extensively (Rossi et al. 2015). Although already recorded in the Brazilian state of Minas Gerais, its occurrence is less relevant than several other triatomine species that occur in the northern part of the state. In the sylvatic, T. sordida and T. pseudomaculata are found under tree bark and crevices, and their life cycles depend on the biology of the sylvatic animals that serve as their food sources (Diotaiuti et al. 1993).

Northern Minas Gerais has boundaries with the Brazilian Northeast, a region with low social-economic levels and low human development index (HDIs-PNUD). Historically, the region has high rates of T. sordida infestation (Diotaiuti et al. 1995a). The human prevalence of Chagas disease in the Mato Verde municipality in 1979 was $37.9 \%$, and $100 \%$ of analysed dwellings were infested by triatomines (Diotaiuti et al. 1995a). After initiating control programs for $T$. infestans in this region, $T$. sordida persists in colonising both domestic and peridomestic areas (Pires et al. 1999), although the prevalence of the disease has declined to $2.4 \%$ nationally since the 2000s (Martins-Melo et al. 2014). 
Many studies have reported the distribution of triatomines and their association with land cover and climatic variables (Gurgel-Gonçalves et al. 2012, Medone et al. 2015). Layers of land cover and soil obtained from satellite images can be used to monitor species habitat changes. This approach allows the evaluation of conditions that are favourable for the dispersion of the vector as well as its development, reproductive success, and survival (Omumbo et al. 2002). Climate conditions are evaluated using data such as land surface temperature (LST) and the normalised difference vegetation index (NDVI) (Goetz et al. 2000, Guimarães et al. 2010). In general, the deforestation of large rural areas is associated with changes in climate patterns. These changes may interfere with vector potential and thus have epidemiological importance (Gorla et al. 2002).

The objective of the present study is to identify changes in the ecoepidemiology of Chagas disease in an area of northern Minas Gerais by analysing infestation by triatomines in sylvatic and domestic environments, the presence of reservoirs, infection by T. cruzi, and the relationships between these factors and environmental and climatic shifts in the region compared to data obtained in the 1980s by Diotaiuti et al. (1993).

\section{MATERIALS AND METHODS}

Area of study - The study was performed in the municipality of Mato Verde, $15^{\circ} 23^{\prime} 49^{\prime \prime} \mathrm{S}, 42^{\circ} 51^{\prime} 57^{\prime \prime} \mathrm{W}$, which has an altitude of $550 \mathrm{~m}$ and is located in northern Minas
Gerais state (Fig. 1). According to the Köppen-Geiger climate classification system, this region is $\mathrm{BSw}$-semiarid (B) and has a mean total annual precipitation between 380 and $760 \mathrm{~mm}$ (S) and summer rains (w). The region has two well-defined seasons, including dry (during winter) and rainy (during summer). November, December and January are the wettest months, and June, July and August are the driest. The municipality has an estimated population of 12,921 inhabitants and contained 53 rural localities within $706 \mathrm{~km}^{2}$ of territory in 1995. In 1995, the municipality was broken up to create the municipality of Catuti, resulting in a total area of $474 \mathrm{~km}^{2}$.

Mato Verde is in an area of ecological transition within the northeastern savanna (Caatinga) that contains dry forest (deciduous forest), savanna (campo cerrado) and Cerrado sensu strictu. The deciduous forest presents large trees with up to $50 \%$ leaf fall during the dry season.

The rural locality of a municipality is defined by the existence of geographically isolated domiciles surrounding a distant urban area possessing natural or artificial limits. Jurema, a rural locality of the Mato Verde municipality, was selected for this study (Fig. 1). Jurema is located $7 \mathrm{~km}$ from the urban area of the municipality $\left(15^{\circ} 26^{\prime}\right.$ $51.2^{\prime \prime} \mathrm{S}$ and $42^{\circ} 51^{\prime} 56^{\prime \prime} \mathrm{W}$ ), occupies an area of $20.27 \mathrm{~km}^{2}$, and suffered strong effects from cotton plantation activity during the 1980s. At that time, Jurema showed high rates of home infestation by triatomines (Diotaiuti et al. 1993). The locality had 38 and 52 houses in 1985 and 2008, respectively, and included discontinuous forest fragments.
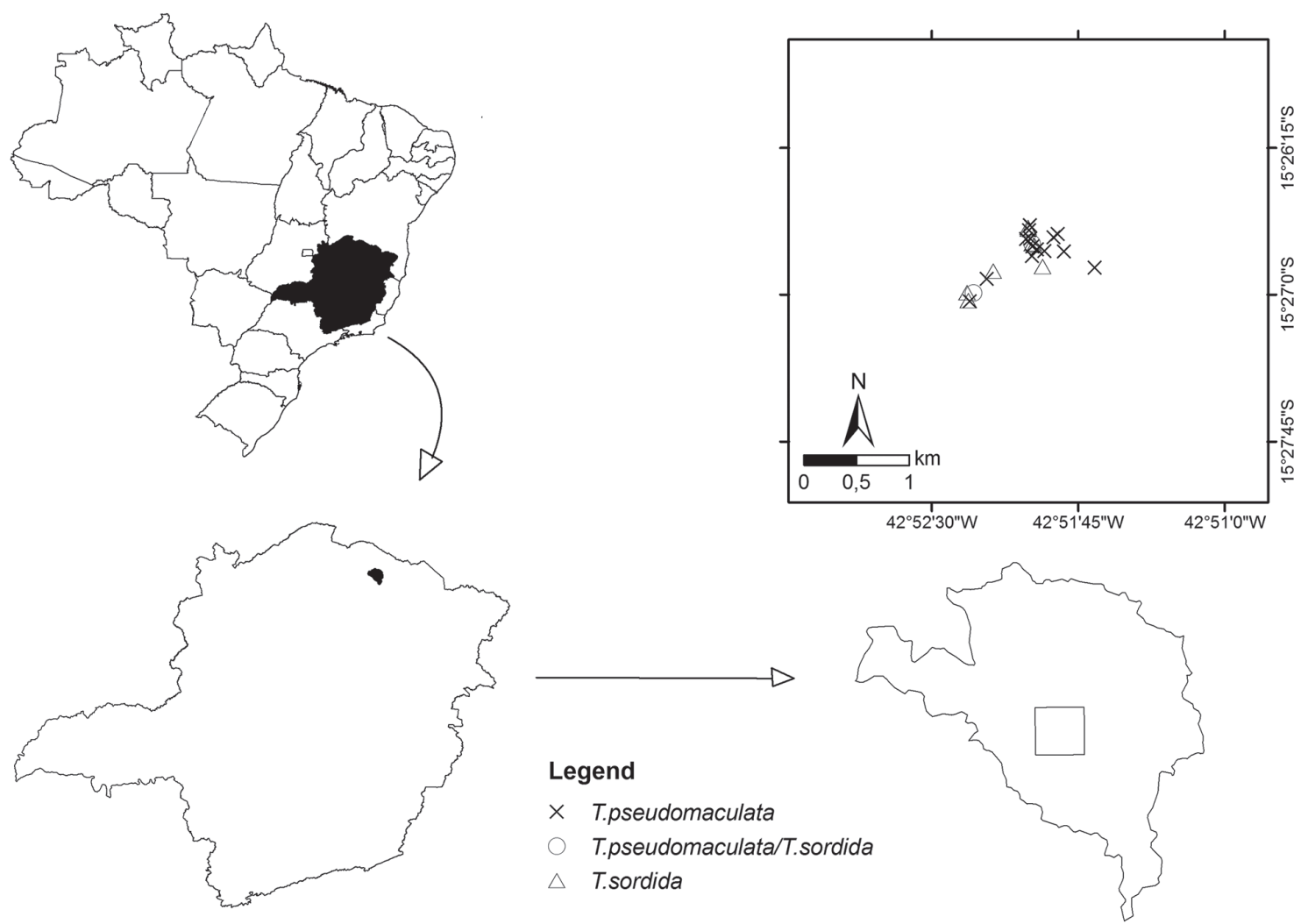

Fig. 1: the locality selected for the study in the municipality of Mato Verde, in Jurema, showing the collection points for triatomines in $2007 / 2008$ and maps of Minas Gerais state, Brazil, that were constructed in ArcGIS. 
Data collection: entomological data from the domestic environment - The historical entomological information used to evaluate the occurrence of triatomines and $T$. cruzi infection in the locality of Jurema in the municipality of Mato Verde (according to the methodology recommended by World Health Organization) was gathered from control programme reports. From 1982 to 1986 , insect collection in domiciles was carried out semi-annually cycles in all houses of the rural locality, and infested houses were sprayed with BHC (30\% hexachlorobenzene). From 1986 to 2000, pyrethroid insecticides were introduced in the control programme, and the cycles of research and spraying became annual. Beginning in the year $2000,50 \%$ of the rural localities were surveyed in one year, and the remaining $50 \%$ were surveyed in the following year to make a biennial survey. To sample triatomines, the Chagas Disease Control Program (CDCP) used the man-hour method for $60 \mathrm{~min}$ in each domiciliary unit (intra- and peridomicile, using $2 \%$ Pirisa $^{\circledR}$ as a dislodge chemical) until 1986.

Entomological data from the sylvatic environment - During the present study, triatomine collection from the sylvatic environment was carried out in the Jurema locality in July 2007 and in February 2008 in six forest fragments. Collection techniques included active searches and live bait traps. Six transects (one per forest fragment) were marked from the village centre (200 to 400 metres), and searching stations were placed approximately every 10 metres. Branches were cut, and bark was removed using knives and axes, and the captured triatomines were kept in individual pots. Five people participated in the capture, and they worked for $4 \mathrm{~h}$ in each forest fragment. In February 2008, surveyed and positive ecotopes were recorded. Fifteen to 20 live baittraps (Noireau et al. 2002) were also distributed among the ecotopes (two to three per ecotope) using a mouse as bait. For purposes of comparison, the data on triatomine captures were used for forest fragments in the same rural location from the surveys completed between September 1985 and 1986. These data were obtained through a study by Diotaiuti et al. (1993), which included an active search of stones and a dissection of live or dead tree trunks and tree bark. On that occasion, the captures were carried out by two people.

During the 2007-2008 period of the present study, potential T. cruzi reservoirs (sylvatic mammals) were captured in the same forest fragments that were surveyed between 1985 and 1986 by Diotaiuti et al. (1993). Tomahawk $^{\circledR}$ and cage-like traps were placed that used grains, banana, dried meat, and cod-liver oil as bait. Twelve traps were distributed over six forest fragments, and they were linearly arranged approximately $10 \mathrm{~m}$ apart. Each was placed for two weeks at the end of the afternoon and then surveyed the following morning for five consecutive days. The captured sylvatic animals were anaesthetised using $2.5 \%$ sodium thiopental and submitted to xenodiagnoses. Ten 3rd or 4th-stage Rhodnius neglectus nymphs were used for each animal (Forattini et al. 1976). A sample of each species of captured animal was culled (authorised by the Brazilian Institute of Environment and Renewable Natural Resources IBAMA - license number 11019-1, registration number 1908597). Animal skulls and skins were identified at the Museum of Natural Sciences of the Catholic University of Minas Gerais. The number of sylvatic mammals and the rate of natural infection for $T$. cruzi were compared with the data collected by Diotaiuti et al. (1993).
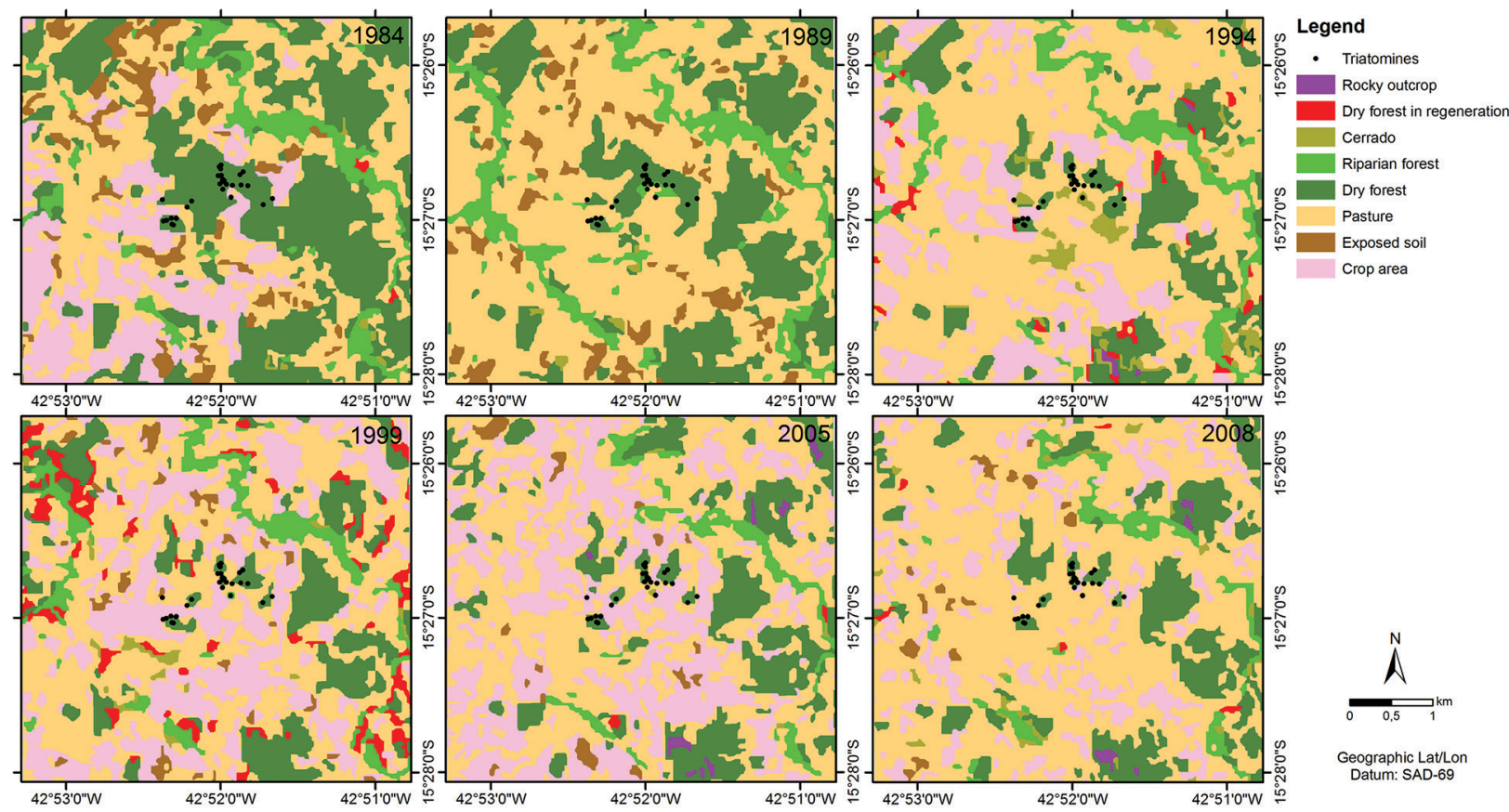

Fig. 2: images classified from Landsat satellite imagery, including retrospectives of Jurema, in Mato Verde, Minas Gerais state, Brazil, that represent land use and land cover and breeding sites of insects collected in 2007/2008. (A) 1984; (B) 1989; (C) 1994; (D) 1999; (E) 2005; (F) 2008. For the matches between colours and classes, see Fig. 3. 


\begin{tabular}{cc}
\hline $\begin{array}{c}\text { Land use class } \\
\text { (R-G-B) }\end{array}$ & Descripition \\
\hline $\begin{array}{c}\text { Rock outcrop } \\
197-0-255\end{array}$ & Chain mountainous with exposed rocks. \\
\hline $\begin{array}{c}\text { Dry forest in regeneration } \\
255-0-0\end{array}$ & Decidous forest in regeneration. \\
\hline $\begin{array}{c}\text { Crop area } \\
255-190-232\end{array}$ & Area used for growing certain crops. \\
\hline $\begin{array}{c}\text { Cerrado } \\
168-168-0\end{array}$ & The vegetation is similar ti the savana, with grasses, shrubs and sparse trees. \\
The climate is seasonal tropical, with dry winters.
\end{tabular}

Fig. 3: definitions of the land use and land cover classes used in the study.

Triatomine identification and T. cruzi infection Adult triatomines were identified according to Lent \& Wygodzinsky (1979), and the nymphs were morphologically compared with standard specimens maintained in the collection of the Centro de Pesquisas René Rachou/FIOCRUZ (René Rachou Research Centre/Oswaldo Cruz Fundation).

Each live insect was submitted to abdominal compression to verify the presence of protozoan flagellates. The parasitological test was performed in fresh triatomine faeces under an optical microscope at 40X and 100X. Triatomine infection with $T$. cruzi was confirmed using multiplex polymerase chain reaction (PCR) (Liarte et al. 2009).

Diotaiuti et al. $(1993,1995 b)$ described capture rates and triatomine infection in the sylvatic as well as the identification of reservoirs that were found to be positive for $T$. cruzi in this locality in the 1980s using zymodeme analysis. Past and present data were subjected to qualitative and quantitative comparison using Fisher's exact test.

Environmental and spatial analysis - Environmental modifications in the region were evaluated using data related to land use and land cover and soil surface temperature using Landsat image processing. They were estimated specifically for the chosen rural locality. For the entire municipality, data were gathered from croplivestock and demographic censuses for the years 1980, 1985, 1996 and 2006. The data included the area planted with cotton cultivation, the quantity of each farm animal, the area used as pasture, and the area covered by natural forests. Data were obtained from the Instituto Brasileiro de Geografia e Estatística (IBGE) (Brazilian Institute of Geography and Statistics).

A global positioning system (GPS) receiver (Garmin eTrex ${ }^{\circledR}$ ) was used to obtain the spatial coordinates of Triatoma spp. breeding sites in July 2007 and February
2008. The georeferenced database was processed using SPRING software (http://www.dpi.inpe.br/spring/), and the appropriate ArcGIS (http://www.esri.com/) algorithms were applied on the Landsat imagery to carry out the classification and atmospheric correction, segmentation, and mapping and to analyse the data obtained in the field. The results are shown in the form of thematic maps.

Images from the satellite LANDSAT TM 5 that were obtained on 08/07/1984, 04/06/1989, 18/06/1994, $31 / 05 / 1989,16 / 06 / 2005$ and 26/07/2008 were collected from the catalogue of images from the National Institute for Space Research with the objective of creating maps of land use and land coverage. Colour images were obtained using composition RGB 543. The atmospheric correction was performed by applying contrast.

The applied method for the classification of the images was segmentation in SPRING software version 4.3.3. The pixel groups were analysed with a similarity of 10 and five for minimal pixel area. After the homogeneous regions were created, a non-supervised method (Isoseg) was applied that allowed the software to identify the maximum possible classes from the specified parameters. The result of the classification was converted from raster to vector and run in the program ArcGIS 9.3 to define the final classes according to the floristic survey. The eight following classes of land use and coverage were considered: rocky outcrop, dry forest in regeneration, crop area, Cerrado, riparian forest, dry forest, exposed soil, and pasture (Fig. 3). SPRING software was also used to compare the classified images from 1984 and 2008 using the LEGAL language. LEGAL is a Map Algebra tool that compares pixel by pixel differences in vegetation between two time points. Therefore, any modification that occurs in the vegetation will produce a response as either in the same class (i.e., no modification occurred) or in a different class (i.e., modification occurred). 
A total of eight classes were used to evaluate changes in land use and land cover in the study period (Fig. 2). The eight classes were grouped into three classes for a better comparison (Fig. 3). "Same class" was used to represent the classes that did not change between years 1984 and 2008. Changes were divided into "another class" and "deforestation" classes. The "deforestation" class indicated changes from one vegetation class (i.e., Cerrado, riparian forest or dry forest) to another nonvegetation class (i.e., rocky outcrop, crop area, exposed soil or pasture). To diagnose vegetative modifications, a Pearson's correlation test was applied to compare the area in square metres that was occupied by each class.

To evaluate changes in the temperature of the rural locality during the study period, the thermal band of Landsat images was used to estimate the surface temperature. For these analyses, we extracted pixel values for minimum, average, and maximum land surface temperature $\left({ }^{\circ} \mathrm{C}\right)$ during the study period.

For the transformation of pixel intensity (0-255), we used the quadratic regression model described by Malaret et al. (1985) (Equation 1), which is included in ArcGIS 9.3. The equation is shown below:

$\mathrm{T}=209.831+0.834 \mathrm{DN}-0.00133 \mathrm{DN} 2$, where: $\mathrm{T}=$ apparent temperature in Kelvin (K), and DN = the digital number of each pixel.

As a final step, Kelvin degrees were converted to Celsius $\left({ }^{\circ} \mathrm{C}\right)$.

To assess possible changes in the local climate, normal climatic measurements from the years 1979-2008 were made by the Brazilian Instituto Nacional de Metereologia (INMET) (National Institute of Meteorology) at the Brazilian meteorological station in Monte Azul, which is located $25 \mathrm{~km}$ from the municipality. Data were considered for the periods 1979-1982 and 1990-2008, and the series data were obtained for the drier and wetter months for the following variables: precipitation $(\mathrm{mm})$, minimum temperature $\left({ }^{\circ} \mathrm{C}\right)$, maximum temperature $\left({ }^{\circ} \mathrm{C}\right)$, and humidity $(\%)$. The means for climate variables were calculated for months with values that were available for each year except for precipitation, which was calculated as the sum of the values of the months. The years that had three or fewer values (for months) were excluded from the analysis. A simple linear regression was performed using the climate data means as the response variable (y) and the year as the explanatory variable (x). All analyses were performed using SPSS 15.0.

\section{RESULTS}

Table I describes the temporal changes in infestation observed in rural homes in Jurema between 1982 and 2014. Changes in the triatomine population were observed over the years after $T$. infestans infestations were eliminated, and the last specimen was captured in 1987. T. sordida was the dominant species, and it persists throughout the years. T. pseudomaculata was extremely rare (one specimen was identified in 1990). The rate of T. cruzi infection in triatomines fluctuated over time for the species.

In the sylvatic, there were fewer ecotopes infested by triatomines in 2007/2008 (Table II) than in 1985/1986 ( $\chi^{2}$,

TABLE I

Infestation, number of insects, infection by Trypanosoma cruzi of triatomines captured in the domiciliary units (DUs) of the rural locality of Jurema, city of Mato Verde, Minas Gerais state, Brazil, in the 1982-2014 period

\begin{tabular}{|c|c|c|c|c|c|c|}
\hline Year & DUs surveyed & $\mathrm{N}^{\mathrm{o}}$ of infested DUs/II (\%) & Triatoma infestans & T. sordida & $\begin{array}{c}\text { NIR } \\
\text { (T. infestans) }\end{array}$ & $\begin{array}{c}\text { NIR } \\
\text { (T. sordida) }\end{array}$ \\
\hline 1982 & 34 & $13(38.2)$ & 14 & 51 & 0 & 0 \\
\hline 1983 & 37 & $17(45.9)$ & 14 & 81 & 15.4 & 0 \\
\hline 1984 & 39 & $7(17.9)$ & 4 & 43 & 33.3 & 0 \\
\hline 1985 & 38 & $14(36.8)$ & 20 & 66 & 6.25 & 4.3 \\
\hline 1986 & 41 & $13(31.7)$ & 10 & 57 & 25 & 3.5 \\
\hline 1987 & 44 & 1329.4 & 6 & 91 & 0 & 0 \\
\hline 1988 & 42 & $5(11.9)$ & 0 & 13 & - & 0 \\
\hline 1989 & 44 & $19(43.2)$ & 0 & 69 & - & 0 \\
\hline 1990 & 50 & $18(36)$ & 0 & 58 & - & 0 \\
\hline 1991 & 51 & $19(37.3)$ & 0 & 58 & - & 11.3 \\
\hline 1992 & 51 & 25 (49) & 0 & 62 & - & 0 \\
\hline 1993 & 49 & $10(20.4)$ & 0 & 25 & - & 0 \\
\hline 1996 & 50 & $31(62)$ & 0 & 105 & - & 0 \\
\hline 2005 & 46 & $54.3(25)$ & 0 & 52 & - & 0 \\
\hline 2007 & 44 & $21(47.7)$ & 0 & 142 & - & 1.8 \\
\hline 2009 & 56 & $55.4(31)$ & 0 & 60 & - & 0 \\
\hline 2014 & 56 & $42.9(24)$ & 0 & 53 & - & 0 \\
\hline
\end{tabular}

II: infestation index (number of positive domiciliary units for triatomines/number of domiciliary units inspected x 100). NIR: natural infection rate $=$ number of positive triatomines for $T$. cruzi, divided by the number of examined triatomine X 100. Source: FUNASA-Ministry of Healthy. One exemplar of Triatoma pseudomaculata in 1990 is not included in the Table. 
$\mathrm{p} \leq 0.0001$ ). The total number of T. pseudomaculata and $T$. sordida captured in both periods differed (Fisher's exact test, $p<0.0001$ ), and there was a reduction in the number of captured T. sordida and an increase in the number of captured T. pseudomaculata. The average number of insects captured per ecotope was 1.83 for $1985 / 86$ and 0.73 for 2008, and the difference between the two is not statistically significant. There was a trend towards a reduction in the T. cruzi infection rate in the triatomines and reservoirs, although the result of Fisher's exact test was not significant for either triatomine infection $(p=0.116)$ or the reservoirs $(p=0.159)$ in either survey period (Table III). In the 1985/1986 period, all infected mammals belonged to the species Didelphis albiventris. In 2007, out of 11 captured mammals, one $D$. albiventris was infected (captured in the forest, $500 \mathrm{~m}$ from a house) as was one Cerradomys sp. (captured in a house barn) (see Table III). No triatomines were caught by live bait traps.

Table IV shows the data from the crop-livestock census of the municipality for 1980, 1985, 1996, and 2006. There was an increase in pasture area, a reduction in forest area (e.g., Cerrado, deciduous seasonal forest, riparian forest, and deciduous seasonal forest in regeneration), a reduction in the area encompassing cotton crops, a reduction in cattle in the region, and a slight increase in goat numbers, whereas poultry numbers remained stable. Fig. 2 shows the results of the analysis of land use and land coverage estimated using satellite images in the years with the respective classes for the rural locality, and Fig. 3 shows the definition of the vegetation classes used in the study. The LEGAL analysis revealed deforestation and changes in deciduous forest, riparian forest and Cerrado in open areas (Pasture and crop areas). Table V shows the changes in the percentages of the classes between 1984 and 2008 and highlights the most relevant ones (six classes). A total of $19.9 \%$ of the area occupied by deciduous seasonal forest, Cerrado and riparian forest was converted into pasture between 1984 and 2008, 0.03\% was converted into exposed soil, and $2.8 \%$ was converted into crop areas, for a total of $22.8 \%$ deforestation in the area.

Spearman's rank correlation coefficient identified a statistically significant and negative correlation between the changes that occurred throughout the years between the forest (deciduous and riparian forest) and the crop area (pasture and open areas) $(\mathrm{r}=-0.885, \mathrm{p}=0.019)$.

Table VI shows the LST values for 1984, 1989, 1994, 1999,2005 and 2008 . The LST mean ranged from $21.42^{\circ} \mathrm{C}$ in 1984 to $28.5^{\circ} \mathrm{C}$ in 2008 , with the highest value of $32.39^{\circ} \mathrm{C}$ recorded in 1999 . Analyses using Pearson's and Spearman's correlation tests between the vegetation and LST classes did not find statistically significant results.

Table VII shows the maximum and minimum temperatures in the dry and wet seasons, demonstrating a trend toward an increase between seasons.

For each year considered in the region, there was an increase of $0.033^{\circ} \mathrm{C}$ in the monthly minimum temperature in the dry season months. For the wet season, there was an increase of $0.044^{\circ} \mathrm{C}$. The maximum temperature in the wet season increased by $0.051^{\circ} \mathrm{C}$, and in the dry season, it increased by $0.044^{\circ} \mathrm{C}$ according to a regression coefficient, as shown in Table VII. All coefficients were statistically significant. There were no significant differences in analyses involving precipitation and humidity variables (data not shown).

\section{TABLE II}

Rural locality of Jurema, Mato Verde, Minas Gerais state, Brazil. Triatomines caught in the wild during 1985/1986 and 2007/2008

\begin{tabular}{lcccccc}
\hline Research period & Days worked & $\begin{array}{c}\text { Ecotopes } \\
\text { researched }\end{array}$ & $\begin{array}{c}\text { Ecotopes } \\
\text { infested }\end{array}$ & Triatoma sordida & T. pseudomaculata & Total \\
\hline $\begin{array}{l}\text { September-August } \\
1985 / 1986\end{array}$ & 35 & 105 & $37(35.2 \%)$ & $68(97.1 \%)$ & $2(2.9 \%)$ & $70(100 \%)$ \\
July/2007 & 5 & $*$ & 10 & $5(29.4 \%)$ & $12(70.5 \%)$ & $17(100 \%)$ \\
February/2008 & 5 & 332 & $19(5.7 \%)$ & $14(53.8 \%)$ & $12(46.2 \%)$ & $26(100 \%)$ \\
\hline
\end{tabular}

*: ecotopes researched but not counted.

\section{TABLE III}

Parasitological examination of mammals and triatomines infected with Trypanosoma cruzi in the wild in the Brazilian locality of Jurema, Mato Verde, Minas Gerais state

\begin{tabular}{|c|c|c|c|c|}
\hline & $\mathrm{N}^{\mathrm{o}}$ of mammals & $\mathrm{N}^{\circ}$ of mammals infected & $\begin{array}{l}\mathrm{N}^{\mathrm{o}} \text { of collected } \\
\text { triatomines/examined }\end{array}$ & $\mathrm{N}^{\mathrm{o}}$ of triatomines infected \\
\hline 1985-1986 & $37 *$ & $15(40.5 \%)$ & $68 / 64$ & $7(10.9 \%)$ \\
\hline $2007-2008$ & $11^{* *}$ & $2(18.2)$ & $26 / 22$ & 0 \\
\hline
\end{tabular}

*: 30 Didelphis albiventris and seven Thrichomys apereoides; **: three D. albiventris, seven T. apereoides and one Cerradomys sp. 
TABLE IV

Data from the Instituto Brasileiro de Geografia e Estatística (Brazilian Institute of Geography and Statistics) Agricultural Census of use and land cover in the municipality of Mato Verde, Minas Gerais state, for period between 1980 and 2006

\begin{tabular}{lcccccc}
\hline Year & Pastures (ha) & Woods (ha) & Cattle (n) & Goats (n) & Poultry (n) & Cotton farming (ha) \\
\hline 1980 & 10.229 & 23.556 & 25.000 & 300 & 32.000 & 18.970 \\
1985 & 8.988 & 17.149 & 22.666 & 250 & 26.356 & 18.000 \\
1996 & 8.358 & 11.650 & 28.950 & 250 & 29.700 & 4.650 \\
2006 & 24.459 & 9.919 & 13.605 & 2.050 & 27.956 & 1.300 \\
\hline
\end{tabular}

ha: hectares; n: number of animals.

TABLE V

Matrix showing the difference between the 1984 and 2008 classifications (\%) using LEGAL language

\begin{tabular}{lccccccc}
\hline 1984\2008 & Cerrado & Riparian forest & Dry forest & Pasture & Exposed soil & Crop area & Total \\
\hline Cerrado & 0.021 & 0.056 & 0.235 & 0.077 & 0.000 & 0.005 & 0.394 \\
Riparian forest & 0.407 & 2.611 & 0.51 & 2.929 & 0.003 & 0.139 & 6.599 \\
Dry forest & 0.612 & 0.288 & 13.453 & 16.932 & 0.022 & 2.657 & 33.96 \\
Pasture & 0.380 & 0.758 & 2,003 & 24.521 & 0.651 & 6.991 & 35.3 \\
Exposed soil & 0.009 & 0.025 & 0.038 & 4.659 & 0.197 & 1.134 & 6.06 \\
Crop area & 0.128 & 0.137 & 0.281 & 12.989 & 0.379 & 3.771 & 17.69 \\
\hline Total & 1.557 & 3.875 & 16.52 & 62.107 & 1.252 & 14.697 & 100 \\
\hline
\end{tabular}

TABLE VI

Land surface temperature (LST) in degrees celsius $\left({ }^{\circ} \mathrm{C}\right)$ for Jurema, Minas Gerais state, in the years 1984 to 2008

\begin{tabular}{lcccc}
\hline & Minimum & Mean & Maximum & SD \\
\hline 1984 & 16.46 & 21.42 & 25.09 & 1.6 \\
1989 & 23.13 & 28.33 & 32.08 & 1.63 \\
1994 & 22.13 & 27.68 & 32.08 & 1.63 \\
1999 & 27.01 & 32.39 & 37.67 & 1.76 \\
2005 & 20.1 & 24.75 & 27.96 & 1.35 \\
2008 & 21.2 & 28.5 & 33.41 & 1.92 \\
\hline
\end{tabular}

SD: standard deviation.

\section{DISCUSSION}

The present study reveals new information regarding the ecoepidemiology of CD in a municipality in northern Minas Gerais. We compared two different time periods (1985/86 and 2007/08) and found that T. sordida continues to colonise domiciles, and in the sylvatic environment its abundance was reduced, as were the number of ecotopes infested. The abundance of T. pseudomaculata has increased, while environmental changes occurred simultaneously in the region and were mainly associated with vegetation and temperature. There was a reduction in riparian forest, Cerrado, and deciduous forest and an increase in pasture, crop, and exposed soil areas.
The CDPC started in 1982 after T. infestans elimination from the municipality. T. infestans was eliminated from domiciliary units in 1986, although this did not occur with the native species, $T$. sordida. The existence of complex peridomiciles in the locality may be a fundamental factor in the maintenance of colonisation by T. sordida, which finds shelter among different structures, crevices, and holes, hindering its control (Diotaiuti et al. 1995a). Peridomiciliary infestation by this species in the Brazilian states of São Paulo, Minas Gerais, and Goiás was associated with the presence of animal shelters built with wood (e.g., chicken coops and corrals), piles of firewood or wood, and food storage (Diotaiuti et al. 1993, Rossi et al. 2015), as was also observed in the present study region.

In the domicile units of Jurema, the natural T. cruzi infection rate fluctuated between 1.8 and $11.3 \%$, probably due to the presence of triatomines and sylvatic reservoirs, which introduce the parasite into the transmission cycle near dwellings. Infected Cerradomys sp. and $D$. albiventris were found in peridomicile areas and sylvatic environments, respectively, demonstrating the synanthropic behaviour that is frequently observed in agricultural areas (Pereira \& Geise 2007). This provides a link between sylvatic and artificial environments.

A comparison of the present data with those of Diotaiuti et al. (1993) demonstrates that important changes have occurred in the sylvatic environments of the Jurema locality, including decrease in the number of infected triatomines and reservoirs, the number of positive ecotopes, and the prevalence of triatomine species. Data for $2007 / 2008$ captures demonstrated a predominance of $T$. 


\section{TABLE VII}

Results of the linear regression test between the values of maximum and minimum temperatures aggregated by months of the dry season (D) and rainy season (R). Monte Azul Meteorological Station, Minas Gerais state, Brazil

\begin{tabular}{|c|c|c|c|c|}
\hline & Regression coefficient $(\beta)$ & Standard error & T-value & $\operatorname{Pr}(>|t|)$ \\
\hline Year (Tmin R) & 0.033 & 0.008 & 4.163 & $5.68 \mathrm{e}-05$ \\
\hline Year (Tmin D) & 0.044 & 0.0145 & 2.952 & 0.008 \\
\hline Year (Tmax R) & 0.051 & 0.017 & 3.029 & 0.003 \\
\hline Year (Tmax D) & 0.044 & 0.014 & 3.128 & 0.002 \\
\hline
\end{tabular}

pseudomaculata over T. sordida, while the data obtained in 1985/1986 showed that the most abundant species was T. sordida. T. pseudomaculata presents a wide distribution in the Brazilian semiarid region (endemic area), predominantly in the Caatinga, and reaches the transition areas of savanna/Caatinga in northern Minas Gerais. In the northeast part of Brazil, its behaviour is like that of T. sordida in that it colonises mainly peridomiciles but can also colonise intradomiciles (Assis et al. 2009). This similarity is maintained in the sylvatic environment, where it is found in hollows and under tree bark (Carbajal de la Fuente et al. 2007), which probably furthers the expansion of $T$. pseudomaculata to new territories where conditions are more favourable. This process was observed in Berilo, Minas Gerais, where T. pseudomaculata began to predominate over Panstrongylus megis$t u s$, a species traditionally associated with regions with higher humidity, probably due to increased soil aridity, which favours caatinga species (Assis et al. 2007).

The sites sampled in fragments of the Jurema forest are classified as a mosaic of deciduous seasonal forest because their structural and floristic composition includes elements of Caatinga vegetation and Cerrado. The present study shows that deforestation has increased over the course of the study period. Deforestation produced open areas (Pasture and crop areas). The reduction of $T$. sordida in the sylvatic environment and the reduction in the percentage of ecotopes infested with triatomines observed since the 1980s may be related to the decrease in habitat available for hosts, which are caused by reductions in the area covered by deciduous forest, Cerrado and riparian forests.

There was a change in mean LST in the region between the years 1984 and 2007-2008, probably because of an increase in crop area, exposed soil, and pasture. Some studies of climatic alterations in South America have shown that during the last 50 years, soil surface temperatures have increased by $0.75^{\circ} \mathrm{C}$, whereas minimum air temperatures have increased up to $1^{\circ} \mathrm{C}$ (IPCC 2011). One factor that some authors suggest contributed to these climate alterations in certain regions is deforestation, as shown in the present work. When there is an increase in the micro-climate temperature, there are increases in the triatomine egg eclosion rate, vector reproduction, and dispersion (Curto de Casas et al. 1999), as has already been shown in mathematical models of the occurrence of $T$. infestans (Gorla 2002). These environmental changes may partially explain the sylvatic expansion of T. pseudomaculata, a species typical of semiarid climate and vegetation.
The combined use of GIS and statistical techniques indicates the occurrence of significant changes in land cover, especially those related to increases in local pasture at the expense of native forest, as well as significant changes in LST. The LEGAL analysis allows researchers detect transformations in land use and land coverage classes and is more accurate than values obtained directly from satellite images (Barbosa 1997). The algorithm revealed the extent of deforestation that had occurred in the locality.

The density of T. sordida in sylvatic ecotopes is characteristically low. A comparison between the data described in Diotaiuti et al. (1993) and the present study indicates that the number of specimens per positive ecotope has varied between one and three insects. Forattini et al. (1983) periodically surveyed over 700 ecotopes in an area of Cerrado and captured only 76 specimens of $T$. sordida in a year. Noireau et al. (1999) captured T. infestans and T. sordida in Bolivia using live bait traps in tree hollows and obtained a density of individuals of 1.3 to 1.8 per ecotope sampled. The sylvatic ecotopes used by $T$. sordida are considered "unstable" in that they are subject to greater microclimate variation and seasonality of food sources (Diotaiuti 2009). Therefore, the observed climate changes are expected to alter ecotope microclimate and to favour the occurrence of $T$. pseudomaculata, specifically where there is lower humidity and higher temperatures. The results presented here may also be useful for assessments of environmental integrity because the effects of changes in triatomine ecology probably occur in parallel with effects on other organisms and involve unknown consequences for the natural environment.

\section{ACKNOWLEDGEMENTS}

To the Regional Health Management of Montes Claros, João Resende, Aparício Fernandes, Geraldo Assis and Tranquilino Rocha, and the field agents of the Mato Verde $\mathrm{Mu}-$ nicipal Health District. We are grateful to Professor Carlos Henrique Jardim (IGC/UFMG), for his help with the climatological analysis, and to Professor Mário do Espírito Santo (UNIMONTES), for his help with the diagnosis of the phytophysionomy of northern Minas Gerais state. To all others who contributed to this work, we offer our sincere gratitude.

\section{AUTHORS' CONTRIBUTION}

ENV - Responsible for performing and analysing the data, writing the manuscript, and performing field and laboratory work, and this work constituted part of her doctoral thesis; RJPSG - responsible for the LEGAL analysis of classes ob- 
tained from satellite image processing; CRS - carried out the entire geoprocessing analysis of satellite images; DG - performed the statistical analyses of environmental and climate variables and improved the objectives and methodologies used in this study; LD - responsible for the study design, coordination and execution, she was a mentor during the project that gave rise to this work, and participated in its writing.

\section{REFERENCES}

Assis GFM, Azeredo BVM, Carbajal de la Fuente AL, Diotaiuti L, de Lana M. Domiciliation of Triatoma pseudomaculata (Corrêa e Espínola 1964) in the Jequitinhonha Valley, State of Minas Gerais. Rev Soc Bras Med Trop. 2007; 40(4): 391-6.

Assis GFM, Azeredo BVM, Gorla D, Diotaiuti L, de Lana M. Entomological surveillance of Chagas disease in Berilo municipality, Jequitinhonha Valley, State of Minas Gerais, Brazil. Rev Soc Bras Med Trop. 2009; 42(6): 615-21.

Barbosa CCF. Álgebra de mapas e suas aplicações em sensoriamento remoto e geoprocessamento [Dissertação de Mestrado]. São José dos Campos: Instituto de Ciências Espaciais-INPE; 1997. 157 pp. Available from: http://mtc-m12.sid.inpe.br/col/dpi.inpe.br/ banon/1998/05.07.15.37/doc/publicacao.pdf?languagebutton=en.

Carbajal de la Fuente AL, Minoli SA, Lopes CM, Noireau F, Lazzari CR, Lorenzo MG. Flight dispersal of the Chagas disease vectors Triatoma brasiliensis and Triatoma pseudomaculata in northeastern Brazil. Acta Trop. 2007; 110(2): 115-9.

Carcavallo RU, Girón IG, Juberg J, Lent H. Distribuição geográfica e dispersão altilatidudinal. In: Carcavallo RU, Galíndez-Girón I, Jurberg J, Lent H, editors. Atlas dos vetores da doença de Chagas nas Américas. Vol. III. Rio de Janeiro: Fiocruz; 1999. 396 pp.

de Casas SIC, Carcavallo RU, Galíndez-Girón I, Burgos JJ. Bioclimatic factors and zones of life. In: Carcavallo RU, Galíndez-Girón I, Jurberg J, Lent H, editors. Atlas of Chagas disease vector in the Americas. Vol. III. Rio de Janeiro: Fiocruz; 1999. 396 pp.

Diotaiuti L, Bezerra CM, Ferraz ML, Gomes A. Transmission of Trypanosssoma cruzi by secondary species. Rev Soc Bras Med Trop. 2009; 42: 100-2.

Diotaiuti L, de Paula OR, Falcão PL, Dias JCP. Avaliação do programa de controle da doença de Chagas em MG, Brasil, com referência especial ao Triatoma sordida. Bol Oficina Sanit Panam. 1995a; 118(3): 211-9.

Diotaiuti L, Loiola CF, Falcão PL, Dias JCP. The ecology of Triatoma sordida in natural environments in two different regions of the state of Minas Gerais, Brazil. Rev Inst Med Trop São Paulo. 1993; 35(3): $237-45$.

Diotaiuti L, Pereira AS, Loiola CF, Fernandes AJ, Schofield JC, Dujardin JP, et al. Inter-relation of sylvatic and domestic transmission of Trypanosoma cruzi in areas with and without domestic vectorial transmission in Minas Gerais, Brazil. Mem Inst Oswaldo Cruz. 1995b; 90(4): 443-8.

Forattini OP, Cotrim MD, Galati EAB, Sarzana SB, Cruz CF, Van Dinteren NHS, et al. Estudo sobre a utilização de Rhodnius neglectus para xenodiagnósticos realizados em marsupiais (Didelphis). Rev Soc Bras Med Trop São Paulo. 1976; 10(4): 335-43.

Forattini OP, Ferreira OA, Rabello EX, Barata JMS, Santos JLF. Aspectos ecológicos da tripanossomíase americana: XVIII-Desenvolvimento e ciclos anuais de colônias de Triatoma infestans, $T$. sordida e Rhodnius neglectus em ecótopos artificiais, no ambiente peri e extradomiciliar. Rev Saude Publica. 1983; 17(4): 243-62.

Goetz SJ, Prince SD, Small J. Advances in satellite remote sensing of environmental variables for epidemiological applications. Adv Parasitol. 2000; 47: 289-304.
González-Brítez N, Carrasco HJ, Purroy CEM, Feliciangeli MD, Maldonado M, López E, et al. Genetic and morphometric variability of Triatoma sordida (Hemiptera: Reduviidae) from the eastern and western areas of Paraguay. Front Public Health. 2014; 2: 149.

Gorla DE. Variables ambientales registradas por sensores remotos como indicadores de la distribución geográfica de Triatoma infestans (Heteroptera: Reduviidae). Ecol Austral. 2002 12(2): 117-27.

Guimarães RJPS, Freitas CC, Dutra LV, Scholte RGC, Martins-Bedé FT, Fonseca FR, et al. A geoprocessing approach for studying and controlling schistosomiasis in the state of Minas Gerais, Brazil. Mem Inst Oswaldo Cruz. 2010; 105(4): 524-31.

Gurgel-Gonçalves R, Galvão C, Costa J, Peterson AT. Geographic distribution of Chagas disease vectors in Brazil based on ecological niche modeling. J Trop Med. 2012; 2012: 15 pp.

IPCC - Intergovernmental Panel on Climate Change. Climate change 2007: impacts, adaptation and vulnerability. Working Group II. Contribution to the Intergovernmental Panel on Climate Change Fourth Assessment Report - Summary for Policymakers. 2011 [cited 2011 Jan 30]. Available from: https://www.ipcc.ch/pdf/assessment-report/ar4/wg2/ar4_wg2_full_report.pdf.

Lent H, Wygodzinski P. Revision of triatominae (Hemiptera: Reduviidae), and their significance as vectors of Chagas disease. Bul Am Mus Nat Hist. 1979; 163: 127-520.

Liarte DB, Murta SMF, Steindel M, Romanha AJ. Trypanosoma cruzi: multiplex PCR to detect and classify strains according to groups I and II. Exp Parasitology. 2009; 123(4): 283-91.

Malaret E, Bartolucci LA, Lozano DF, Anuta PE, Mc Gillen CD. LANDSAT-4 and LANDSAT-5 thematic mapper data quality analysis. Photogramm Eng Remote Sensing. 1985; 51: 1407-16.

Martins-Melo FR, Ramos AN, Alencar CH, Heukelbach J. Prevalence of Chagas disease in Brazil: a systematic review and meta-analysis. Acta Trop. 2014; 130: 167-74.

Medone P, Ceccarelli S, Parham PE, Figuera A, Rabinovich JE. The impact of climate change on the geographical distribution of two vectors of Chagas disease: implications for the force of infection. Philos Trans R Soc B Biol Sci. 2015; 370(1665): 20130560.

Noireau F, Abad-Franch F, Valente SAS, Dias-Lima A, Lopes CM, Cunha V, et al. Trapping triatominae in silvatic habitats. Mem Inst Oswaldo Cruz. 2002; 97(1): 61-3.

Noireau F, Flores R, Vargas F. Trapping sylvatic triatominae (Reduviidae) in hollow trees. Trans R Soc Trop Med Hyg. 1999; 93(1): 13-4.

Oliveira AWS, Silva IG. Distribuição geográfica e indicadores entomológicos de triatomíneos sinantrópicos capturados no estado de Goiás. Rev Soc Bras Med Trop. 2007; 40 (2): 204-8.

Omumbo JA, Hay SI, Goetz RWS, Roger DJ. Updating historical maps of malaria transmission intensity in East Africa using remote sensing. Photogramm Eng Remote Sensing. 2002; 68(2): 161-6.

Pereira LG, Geise L. Karyotype composition of some rodents and marsupials from Chapada Diamantina (Bahia, Brasil). Braz J Biol. 2007; 67(3): 509-18.

Pires HHR, Borges EC, de Andrade RE, Lorosa ES, Diotaiuti L. Peridomiciliary infestation with Triatoma sordida Stal, 1859 in the county of Serra do Ramalho, Bahia, Brazil. Mem Inst Oswaldo Cruz. 1999; 94(2): 147-9.

Rossi JCN, Duarte EC, Gurgel-Gonçalves R. Factors associated with the occurrence of Triatoma sordida (Hemiptera: Reduviidae) in rural localities of Central-West Brazil. Mem Inst Oswaldo Cruz. 2015; 110(2): 192-200. 